\title{
Belajar Saat Covid-19: Pelaksanaan Asesmen Alternatif Dalam Pembelajaran Jarak Jauh Pada Masa Pandemi Di Indonesia
}

\author{
Wulida Wahidatul Masruria ${ }^{*}$ \\ ${ }^{1}$ Universitas Negeri Surabaya, Indonesia \\ *email: wulidaria23@gmail.com
}

\begin{abstract}
The implementation of distance learning in the pandemic situation raises many teachers' or students' problems, especially in the assessment. Distance learning needs media that can link teachers and students, such as laptops, cellphones, internet, audio, video, etc. Therefore, alternative assessment is needed in distance learning to improve the distance learning process. The present study will explore an overview of the alternative assessment in the pandemic situation, especially in Indonesia. This study is a type of library research. The researcher gets the data and literature from the book, journals, previous studies, and other document support. This study showed that two alternative assessments could be used in distance learning. Those are online-based assessments and self-assessment.
\end{abstract}

Keywords: Online-Based Assessment, Self-Assessment, distance learning

\begin{abstract}
Abstrak: Pelaksanaan pembelajaran jarak jauh dalam situasi pandemi menimbulkan banyak masalah bagi guru atau siswa, terutama pada bagian penilaian. Pembelajaran jarak jauh membutuhkan media yang dapat menghubungkan guru dan siswa, seperti laptop, ponsel, internet, audio, video, dll. Oleh karena itu, diperlukan alternatif asesmen dalam pembelajaran jarak jauh untuk meningkatkan proses pembelajaran yang dilakukan secara jarak jauh. Penelitian ini bertujuan untuk memberikan gambaran tentang kajian alternatif dalam situasi pandemi, khususnya di Indonesia. Penelitian ini merupakan jenis penelitian pustaka. Peneliti mendapatkan data dan literatur dari buku, jurnal, penelitianpenelitian sebelumnya, dan dokumen pendukung lainnya. Studi ini menunjukkan bahwa dua alternatif penilaian dapat digunakan dalam pembelajaran jarak jauh. Itu adalah penilaian berbasis daring dan penilaian diri sendiri.
\end{abstract}

Kata Kunci: Penilaian Berbasis Daring, Penilaian Diri, Pembelajaran Jarak Jauh

Copyright (c) 2021 The Authors. This is an open access article under the CC BY-SA 4.0 license (https://creativecommons.org/licenses/by-sa/4.0/)

\section{PENDAHULUAN}

Pandemi COVID-19 telah memberikan berbagai macam dampak pada segala aspek. Penyebaran coronavirus disease atau COVID-19 sangatlah masif sehingga memaksa pemerintah untuk mengeluarkan berbagai macam kebijakan diantaranya kebijakan physical distancing dan social distancing guna memutuskan mata rantai COVID-19. Kebijakan tersebut, juga didukung dengan surat edaran yang dikeluarkan oleh Mendikbud dalam penyelenggaraan pendidikan nasional. Mendikbud Nomor 3 Tahun 2020 tentang Pencegahan Virus COVID-19 pada 
Satuan Pendidikan, dan Surat Edaran Nomor 4 Tahun 2020 Tentang Pelaksanaan Kebijakan Pendidikan Dalam Masa Darurat Penyebaran Coronavirus Disease (COVID-19). Langkah ini merupakan salah satu upaya pemerintah untuk memutuskan mata rantai virus corona dalam satuan pendidikan di Indonesia (Kemendikbud, 2020).

Sehingga, sejak penyebaran COVID-19 di Indonesia pada 11 maret 2020. Model pembelajaran di Indonesia bagi seluruh jenjang baik SD, SMP, SMA dan Pendidikan tinggi mengalami adaptasi, yaitu dengan menggunakan sistem pembelajaran daring. Selain itu, Menteri Pendidikan dan Kebudayaan dalam keputusannya menekankan bahwa kesehatan dan pendidikan saling berhubungan. Sehingga, dalam penyelenggaraan pendidikan harus mengedepankan kesehatan dari peserta didik dan pendidiknya. Karenanya, pembelajaran jarak jauh merupakan salah satu solusi terbaik untuk tetap melakukan pembelajaran tanpa harus bertemu secara fisik (Pakpahan \& Fitriani, 2020) dengan menggunakan fasilitas Internet yang memadai (Prawiyogi, Purwanugraha, Fakhry, \& Firmansyah, 2020). Sejalan dengan hal tersebut, pencegahan penyebaran virus corona melalui dapat dilakukan dengan social distancing, selalu di rumah dan physical distancing. Menurut Sari, Rifki, \& Karmila (2020) pembelajaran jarak jauh merupakan tantangan terbesar bagi guru dan peserta didik, karena yang tadinya mereka dapat belajar bersama didalam kelas kini mereka harus belajar di tempat yang berbedabeda yang tentunya setiap anak memiliki kendala nya masing-masing.

Asesmen dan evaluasi sebagai salah satu komponen pembelajaran yang harus dilaksanakan walau pembelajaran secara daring guna melihat hasil dari pembelajaran yang telah dilakukan oleh peserta didik serta melihat kemajuan belajar peserta didik dan mahasiswa didik (Setiawan, 2020). Bagi seorang pendidik, hasil dari penilaian merupakan salah satu bukti dari keberhasilan baik bagi individu maupun bagi institusi. Sehingga pada masa sekarang, asesmen dan evaluasi dari pembelajaran dapat dilakukan di tempat masing-masing dengan menggunakan metode assessment jarak jauh guna menaati social distancing and physical distancing (Azzahra, 2020).

Dengan adanya teknologi, tentu hal ini sangatlah memudahkan para pendidik untuk melakukan asesmen dan evaluasi jarak jauh. Pendidik dapat 
memanfaatkan berbagai macam platform yang ada untuk melakukan asesmen dan evaluasi kepada peserta didik dan mahasiswa didik secara daring. Asesmen yang dilakukan dapat berupa kuis, tes daring, penugasan individu, ataupun menggunakan cara lain yang dapat menggunakan jaringan internet (Fadlilah, Budi, \& Widodo, 2021). Akan tetapi, akan muncul berbagai macam kendala bagi mereka yang berada di daerah terpencil di Indonesia yang belum mempunyai sarana internet, sehingga hal ini akan menyusahkan bagi mereka. Permasalahan jaringan internet yang dihadapi oleh pendidik yang berada di daerah terpencil dan pedesaan merupakan salah satu ketimpangan yang sering ditemui di Indonesia. Pasalnya masih banyak wilayah-wilayah di Indonesia yang belum memiliki fasilitas internet yang memadai. Karenanya komunikasi antara murid, guru, dan orang tua sangatlah penting. Menyikapi hal tersebut, maka perlu adanya alternative asesmen dan evaluasi untuk membentuk ruang belajar yang efektif pada pembelajaran jarak jauh (Azzahra, 2020).

Penelitian ini dibuat sebagai salah satu bentuk usaha yang mampu memberikan teori dasar dari alternative asesmen, yang dapat dijadikan acuan bagi pendidik dalam melakukan asesmen dan evaluasi pada peserta didik di masa pandemi COVID-19. Peneliti telah melakukan beberapa kajian pustaka terhadap literatur terdahulu yang telah mengkaji tentang asesmen dan evaluasi dalam pembelajaran diantaranya jurnal yang ditulis oleh Wartoni (2020) dengan judul "Disrupsi Asesmen" (Peran Teknologi Dalam Pelaksanaan Asesmen Di Masa Pandemi COVID-19”, yang berisikan peran teknologi sebagai salah satu alat penting dalam implementasi asesmen dan evaluasi di masa Pandemi.

Hasil dari penelitian tersebut menyatakan bahwa teknologi sangatlah berperan penting dalam menerapkan asesmen pada masa pembelajaran jarak jauh. Selain itu, jurnal yang ditulis oleh Ismail dengan judul Inovasi Evaluasi Hasil Belajar Pendidikan Agama Islam, yang menjelaskan tentang teori dasar dan cara implementasi dari model-model evaluasi dan asesmen yang efektif pada pendidikan agama islam (Santika, 2020). Hasil dari penelitian ini menyatakan bahwa pada saat pemebalajaran jarak jauh inovasi dari guru sangatlah dibutuhkan oleh peserta didik untuk menjadikan pembelajaran yang lebih efisien dan efektif khususnya pada pembelajaran pendidikan agama islam. Jurnal yang ditulis oleh Agus Yudiawan 
yang berjudul Belajar Bersama Covid 19: Evaluasi Pembelajaran Daring Era Pandemi Di Perguruan Tinggi Keagamaan Islam Negeri, Papua Barat yang menjelaskan tentang kepuasan mahasiswa didik stain sorong terhadap asesmen jarak jauh yang dilakukan oleh dosen mereka (Yudiawan, 2020).

Hasil dari penelitian ini menyatakan bahwa masih banyak mahasiswa di Perguruan Tinggi Keagamaan Islam Negeri Sorong yang tidak puas dengan pelaksanaan evaluasi pembelajaran jarak jauh. Selanjutnya, jurnal yang berjudul Model Pembelajaran Dominan Online (Domon) di SMA Terbuka Kepanjen yang ditulis oleh Rizal, yang menjabarkan tentang hasil penelitian deskriptif yang dilakukan di SMA Terbuka Kepanjen dengan menggunakan model pembelajaran dominan online (Rizal, 2018). Hasil dari penelitian ini mengatakan bahwa untuk membuat pembelajaran secara online yang efektif dan efisien maka guru harus selalu inovatif. Berdasarkan penelitian-penelitian sebelumnya, maka peneliti melakukan penelitian tentang pelaksanaan asesmen alternatif dalam pembelajaran jarak jauh, yang mana isu ini masih sangat relevan dengan keadaan Indonesia pada saat ini.

\section{METODE}

Studi ini menggunakan model penelitian keperpustakaan (library research).

Yang mana, jenis penelitian ini menggunakan salah satu model penelitian yang menggunakan data-data dari keperpustakaan atau literatur yang telah ada, baik itu dari hard file ataupun soft file yang ada. Jenis penelitian ini dikenal dengan model penelitian kualitatif deskriptif keperpustakaan atau literature. Biasanya diistilahkan dengan penelitian non reaktif karena pada penelitian ini peneliti hanya berfokus ada literatur yang ada dan bersifat teoritis dan dengan menggunakan dokumentasidokumentasi yang ada (Mukhtar, 2013). Pada saat mengerjakan penelitian ini, peneliti memperoleh data-data dari hasil studi literatur, buku-buku, jurnal-jurnal, karya ilmiah serta dokumen-dokumen yang mengkaji perihal asesmen dan evaluasi pada pembelajaran jarak jauh di masa pandemi.

\section{HASIL DAN PEMBAHASAN}

\section{Teori Dasar Asessmen}

Assessment atau penilaian adalah proses yang dilakukan oleh pendidik kepada peserta didiknya untuk mengetahui kemajuan belajar peserta didik (Fadlilah 
et al., 2021) dalam proses pembelajaran. Asesmen sangatlah berbeda dengan tes dan evaluasi. tes merupakan alat untuk mengetahui kemajuan belajar mengajar dengan menghasilkan nilai atau skor. Sedangkan, evaluasi merupakan suatu proses sistematis yang berkelanjutan berdasarkan kriteria yang telah ditentukan (Hardianti, Taufiq, \& Pamelasari, 2017). Selain itu, tujuan dari pelaksanaan evaluasi yaitu guna mendapatkan informasi yang objektif terhadap program tertentu yang telah ditentukan (Widyoko, 2016) Sedangkan asesmen tidak hanya tentang skor atau nilai tetapi lebih berupa feedback dan komentar lainnya yang dapat memberikan perubahan lebih baik kepada peserta didik di dalam proses pembelajaraan. Asesmen lebih mengutamakan proses belajar peserta didik dari pada hasil akhir atau nilai yang di dapat oleh peserta didik (Ahmad, 2020). Penilaian atau asesmen merupakan salah satu kegiatan yang menafsirkan data dari hasil pengukuran kompetensi peserta didik setelah mengikuti proses pembelajaran (Firdaus, Salsabila, \& Mahdalina, 2021)

Ruang Lingkup asesmen dalam proses pembelajaran sangatlah berhubungan dengan peserta didik dan lingkungan kelas (Rachmawati \& Widayani, 2021). Sedangkan ruang lingkup dari evaluasi lebih luas karena mencakup seluruh komponen pembelajaran seperti pendidik, peserta didik, sekolah, kurikulum, dll. Dari penjelasan diatas, dapat diketahui bahwa tes, asesmen, dan evaluasi sangatlah berbeda. Tes merupakan pengukuran, asesmen dan evaluasi memiliki sifat hirarkis. Intinya, dalam pelaksanaannya evaluasi harus didahului oleh asesmen, sedangkan asesmen didahului oleh pengukuran dengan alat ukurnya yang berupa tes.

Dalam upaya meningkatkan kemampuan peserta didik, maka pendidikan melakukan beberapa upaya diantaranya penilaian pada aspek sikap, aspek pengetahuan, dan aspek keterampilan (Ahmad, 2020).

\section{Pembelajaran Jarak Jauh di masa Pandemi}

Pada masa penyebaran virus covid-19 ini pemerintah memerintahkan untuk melakukan pembelajaran jarak jauh. Yang mana proses pembelajaran dilakukan secara jarak jauh baik bagi peserta didik dan guru yang dilakukan dari rumah masing-masing (Yudiawan, 2020). Banyak sekali perbedaan yang ditemui dari pembelajaran jarak jauh dengan pembelajaran konvensional seperti dari cara berinteraksi antara peserta didik dan pendidik, manajemen waktu, teknologi dan 
lain sebagainya. Pembelajaran jarak jauh lebih memanfaatkan media dan teknologi seperti perangkat software dan hardware, multimedia yang interaktif, jaringan internet (Prawiyogi et al., 2020). Sedangkan, pembelajaran konvensional lebih memanfaatkan komunikasi antara pendidikan dan peserta didik di kelas.

Dalam pelaksanaan pembelajaran jarak jauh proses belajar dan mengajar tidak dilakukan secara tatap muka. Peserta didik dan pendidik berada di tempat yang berbeda pada saat pembelajaran berlangsung. Selain itu, dalam penyampaian materinya komunikasi terjadi antara dua arah antara peserta didik dan guru dengan menggunakan alat bantu media seperti gawai, laptop, computer, video, audio dan internet (Firdaus et al., 2021)

Dalam proses pembelajaran jarak jauh seperti ini peserta didik lebih banyak menghabiskan waktunya untuk belajar secara mandiri (Santika, 2020). Karenanya peserta didik diminta untuk dapat menjadi pelajar yang mandiri yang dapat memahami ilmu dengan cara nya sendiri akan tetapi selalu dalam kontrolan pendidik. Banyak sekali hambatan yang dialami peserta didik dan pendidik seperti kurang stabilnya jaringan internet, tidak memiliki media seperti gawai dan laptop hal ini lah yang membuat proses belajar mengajar tidak dapat berjalan lancar seperti pada pembelajaran konvensional (Sari et al., 2020).

\section{Model Asesmen Alternatif dalam Pembelajaran Jarak Jauh di masa Pandemi}

Dalam pelaksanaan pembelajaran di masa pandemi seperti sekarang selain memberikan dampak pada pengelolaan pembelajaran konvensional dan menggantinya dengan pembelajaran jarak jauh (Sari et al., 2020). Juga memberikan dampak pada proses penilaian yang dilakukan oleh peserta didik. Sebagai pendidik harus menggunakan model asesmen atau penilaian alternatif yang berbeda dengan penilaian pada pembelajaran konvensional (Ahmad, 2020). Terdapat beberapa model penilaian yang dapat dilakukan oleh pendidik untuk melakukan penilaian pada masa pembelajaran jarak jauh, yang merujuk pada kebijakan pemerintah Indonesia, diantaranya:

a. Tes Secara Daring

Dalam pelaksanaan tes daring dilaksanakan secara daring dengan menggunakan alat bantu media seperti gawai, computer, laptop dan internet. 
Tes daring dilakukan dengan memanfaatkan teknologi yang ada, jadi peserta didik dan pendidik berada pada tempat yang berbeda tetapi teknologi lah yang membantu proses berlangsungnya tes daring. Pada dasarnya, tes daring sama dengan tes yang dilakukan secara konvensional di dalam kelas, akan tetapi yang membedakan hanyalah tepat pelaksanaannya yang berbeda dan media yang digunakan. Tes konvensional di lakukan di satu tempat tetapi tes daring dapat dilakukan di berbagai tempat antara pendidik dan peserta didik. Menurut Fadlilah et al. (2021) tes merupakan perangkat yang digunakan oleh pendidik untuk mengidentifikasi kemampuan peserta didik dengan cara-cara atau ketentuan yang telah ditentukan. Sebuat tes yang baik yang dapat mengukur kemampuan peserta didik harus mencakup beberapa komponen diantaranya validitas (kesalahan), reliabilitas (keterandalan), Usebilitas (kepraktisan) dan Objektifitas (objektif) (Rachmawati \& Widayani, 2021).

Tes adalah salah satu perangkat yang digunakan oleh pendidik untuk mengukur kompetensi peserta didiknya meliputi aspek pengetahuan dan keterampilan. Selain itu, tes terdiri dari sekumpulan pertanyaan yang harus dijawab atau ditanggapi oleh peserta didik (Prawiyogi et al., 2020). Bentuk dari tes dibagi menjadi dua diantaranya tes subjektif dan tes objektif. Tes subjektif umumnya tes yang berbentuk uraian, selain itu tes essay yang memerlukan jawaban pembahasan atau rangkaian dari uraian kata. Tes subjektif memiliki beberapa ciri-ciri pertanyaan diantaranya: uraikan, bandingkan, simpulkan, jelaskan, dll. Tes objektif yaitu tes yang dilakukan secara objektif. Tes objektif diharapkan mampu mengatasi kelemahan-kelemahan tes objektif seperti tes berbentuk essay (Wartoni, 2020). Selain itu, dalam pelaksanaannya tes objektif dibedakan menjadi empat macam yaitu (a) tes berbentuk benar salah (b) tes berbentuk pilihan ganda (c) tes berbentuk menjodohkan (matching) dan (d) tes isian.

b. Penilaian Diri (Self-Assessment)

Penilaian diri sendiri atau Self-Assessment adalah salah satu penilaian yang memberikan kesempatan kepada peserta didik untuk melakukan penilaian atau tanggung jawab pada diri mereka sendiri tentang proses belajar oleh sebab itu, sebagai pendidik harus memberikan kesempatan kepada peserta didik untuk 
memberikan penilaian pada diri mereka sendiri sebagai validasi atas pemikiran mereka. Penilaian diri sendiri self-assessment adalah salah satu teknik penilaian yang memberikan tanggung jawab kepada peserta didik untuk menilai kemajuan belajar mereka sendiri terkait dengan proses, kompetensi, dan capaian berdasarkan pada tolok ukur atau ketentuan yang telah di tentukan (Azzahra, 2020). Dengan memberikan kesempatan kepada peserta didik untuk melakukan penilaian diri sendiri atau self-assessment berarti pendidik telah melatih peserta didik untuk menjadi peserta didik yang mandiri serta dapat meningkatkan otonomi belajar atau kemandirian belajar (belajar mandiri) pada peserta didik (Panadero, Jonsson, \& Botella, 2017)

Selain itu, dengan melakukan penilaian diri sendiri atau self-assessment peserta didik dilatih untuk mengatur dan mengevaluasi pemikiran serta penampilan diri mereka sendiri serta mampu mengidentifikasi kelemahan dan kelebihan di yang dimiliki sehingga mampu memperbaikinya pada pertemuan selanjutnya dan mampu mencapai hasil belajar yang diinginkan (Borg \& Edmett, 2019). Penilaian diri sendiri atau self-assessment bertujuan untuk mendukung dan memperbaiki proses belajar dan hasil belajar dari peserta didik, karenanya penilaian ini mampu mendukung penilaian yang biasa dipakai sebelumnya (Andrade, 2019).

Penilaian diri sendiri atau self-assessment dapat berfungsi sebagai salah satu perangkat yang digunakan untuk melakukan penilaian pada kompetensi sikap. Seperti yang tertulis di dalam Peraturan Menteri Pendidikan dan Kebudayaan RI No. 66 Tahun 2013 tentang standar penilai pendidikan. Penilaian diri sendiri atau self-assessment ini berfungsi sebagai salah satu perangkat yang dapat meningkatkan karakter peserta didik menjadi lebih baik (Thawabieh, 2017). Terdapat banyak sekali manfaat dari menerapkan penilaian diri sendiri atau self-assessment pada peserta didik diantaranya memberikan reinforcement terhadap kemajuan belajar yang dimiliki oleh peserta didik, membangun rasa percaya diri pada peserta didik, menanamkan karakter jujur, meningkatkan otonomi belajar atau kemandirian belajar (belajar mandiri) pada peserta didik, dan meningkatkan rasa tanggung jawab peserta didik terhadap pelajarannya. 


\section{SIMPULAN}

Sejak ditetapkannya pembelajaran jarak jauh di Indonesia sebagai upaya pemerintah dalam memutuskan mata rantai virus Covid-19 maka peran teknologi sangatlah penting (Pakpahan \& Fitriani, 2020). Proses belajar mengajar jarak jauh menuntut adanya penggunaan teknologi termasuk pelaksanaan asesmen oleh pendidik. Untuk itu, sebagai pendidik dapat menggunakan model alternatif asesmen yang dapat mendukung proses belajar siswa agar lebih efektif (Ahmad, 2020). Pemanfaatan teknologi dalam proses penilaian atau asesmen dapat menciptakan efisiensi dan efektifitas (Sari et al., 2020). Suatu penyelenggaraan pendidikan dapat dikatakan sukses apabila penilaian atau asesmen menunjukkan efektifitasnya. Terdapat beberapa alternatif asesmen yang dapat dilakukan pada proses pembelajaran jarak jauh di masa pandemi Covid-19 diantaranya: penilaian berbasis daring, dan penilaian diri sendiri atau self-assessment.

\section{DAFTAR RUJUKAN}

Ahmad, I. F. (2020). Asesmen Alternatif Dalam Pembelajaran Jarak Jauh Pada Masa Darurat Penyebaran Coronavirus Disease (Covid-19) Di Indonesia. PEDAGOGIK: Jurnal Pendidikan, 7(1), 195-222. https://doi.org/10.33650/pjp.v7i1.1136

Andrade, H. L. (2019). A Critical Review of Research on Student SelfAssessment. Frontiers in Education, 4(August), 1-13. https://doi.org/10.3389/feduc.2019.00087

Azzahra, N. F. (2020). Mengkaji Hambatan Pembelajaran Jarak Jauh di Indonesia di Masa Krisis Pandemi Covid-19. CIPS Center for Indonesian Policy Studies, 19(2), 1-9.

Borg, S., \& Edmett, A. (2019). Developing a self-assessment tool for English language teachers. Language Teaching Research, 23(5), 655-679. https://doi.org/10.1177/1362168817752543

Fadlilah, A. U. N., Budi, S. W., \& Widodo, W. (2021). Penerapan Asesmen Pembelajaran Jarak Jauh Materi Kalor Dan Perpindahannya Secara Daring Dan Luring Di Kelas Vii Smp Negeri 1 Sumberrejo. 9(2), 199204. Retrieved from https://ejournal.unesa.ac.id/index.php/pensa/index Firdaus, A. A., Salsabila, U. H., \& Mahdalina, S. S. (2021). Perubahan Model 
Dan Karakteristik Pembelajaran Pendidikan Agama Islam Di Masa Pandemi Covid-19. Jurnal Pendidikan Dan Kewirausahaan, 8(2), 8797.

Hardianti, R. D., Taufiq, M., \& Pamelasari, S. D. (2017). The development of alternative assessment instrument in web - based scientific communication skill in science education seminar course. Jurnal $\begin{array}{llll}\text { Pendidikan IPA } \quad \text { Indonesia, } & \text { 6(1), }\end{array}$ https://doi.org/10.15294/jpii.v6i1.7885

Pakpahan, R., \& Fitriani, Y. (2020). Analisa Pemafaatan Teknologi Informasi Dalam Pemeblajaran Jarak Jauh Di Tengah Pandemi Virus Corona Covid-19. JISAMAR (Journal of Information System, Applied, Management, Accounting and Researh), 4(2), 30-36.

Panadero, E., Jonsson, A., \& Botella, J. (2017). Effects of self-assessment on self-regulated learning and self-efficacy: Four meta-analyses. Educational Research Review, 22, 74-98. https://doi.org/10.1016/j.edurev.2017.08.004

Prawiyogi, A. G., Purwanugraha, A., Fakhry, G., \& Firmansyah, M. (2020). Efektifitas Pembelajaran Jarak Jauh Terhadap Pembelajaran Siswa di SDIT Cendekia Purwakarta. Jurnal Pendidikan Dasar, 11(01), 94-101. Rachmawati, I., \& Widayani, A. (2021). Sistem Penilaian Kinerja Tenaga Pendidik Dalam Bidang Pembelajaran Dengan 360 Degree Feedback (Studi Kasus Pada Akademi Komunitas Negeri Putra Sang Fajar Blitar). Jurnal Pendidikan Dan Kewirausahaan, 8(2), 138-154.

Santika, I. W. E. (2020). Pendidikan Karakter pada Pembelajaran Daring. Indonesian Values and Character Education Journal, 3(1), 8-19.

Sari, W., Rifki, A. M., \& Karmila, M. (2020). Pembelajaran Jarak Jauh Pada Masa Darurat Covid 19. Jurnal MAPPESONA, (1), 12.

Setiawan, A. R. (2020). Lembar Kegiatan Siswa untuk Pembelajaran Jarak Jauh Berdasarkan Literasi Saintifik pada Topik Penyakit Coronavirus 2019 (Covid-19). Journal of Chemical Information and Modeling, 21(1), 19. https://doi.org/10.1016/j.tmaid.2020.101607\%0A

Thawabieh, A. M. (2017). A Comparison between Students' Self-Assessment 
and Teachers' Assessment. Journal of Curriculum and Teaching, 6(1), 14. https://doi.org/10.5430/jct.v6n1p14

Wartoni. (2020). Distrupsi Asesmen Peran Teknologi dalam Pelaksanaan Asesmen di Masa Pandemi Covid-19. Prosiding Seminar Nasional Pascasarjana, 1(01), 100-107.

Yudiawan, A. (2020). Belajar Bersama Covid 19: Evaluasi Pembelajaran Daring Era Pandemi di Perguruan Tinggi Keagamaan Islam Negeri, Papua Barat. AL-FIKR: Jurnal Pendidikan Islam, 6(1), 10-16. https://doi.org/10.32489/alfikr.v6i1.64 